Титикало В. С., к.е.н., доцент Національний медичний університет імені О. О. Богомольия м. Київ, Україна

DOI: https://doi.org/10.30525/978-9934-26-107-7-12

\title{
КАЗУАЛЬНІ АСПЕКТИ ІННОВАЦІЙНО-ТЕХНОЛОГІЧНОГО РОЗВИТКУ ПІДПРИЕМСТВ МАШИНОБУДУВАННЯ
}

Інноваційно-технологічний розвиток економіки країни процес, значною мірою керований за умови якісної та ефективної державної політики його спрямування та супроводу, де водночас діє й низка внутрішніх та зовнішніх, керованих та некерованих факторів та умов. Відповідно, їх ідентифікація та врахування при формуванні державної політики технологічної модернізації національної економіки дозволяє забезпечити іiі вищу ефективність та тіснішу наближеність до досягнення стратегічних завдань і мети регулювання, знизити умови непередбачуваності, а також нівелювати ймовірні ризики та загрози [1]. Виявлення особливостей інноваційних трансформацій в умовах стрімкого поширення досягнень Індустрії 4.0 має особливу актуальність для промисловості України як пострадянської країни 3 потужним виробничим потенціалом. Історичною передумовою для цього $є$ те, що процеси неоіндустріалізації в нашій країні проходять складніше, ніж в інших країнах, не обтяжених спадщиною радянських промислових гігантів, що за технологічним рівнем належать до Індустрії 2.0 [2]. Саме тому одним із проявів дестимуляторів у галузі машинобудування $є$ порівняно низький рівень інноваційної активності підприємств, що пояснюється довгим виробничим циклом, та призводить до явища за якого машинобудування із перетворення у провідну галузь інновацій залишається на рівні розвитку 90 -х років XX ст.

Рівень інноваційної діяльності машинобудівних підприємств досить складно назвати задовільним, оскільки потреби в 
інноваціях в переважній більшості вони задовольняють за рахунок імпорту інновацій чи необхідного для них устаткування, a не через продукування власних інноваційних розробок, що підтверджується тенденціями наведеними на рис. 1, що спостерігається протягом 10 років.

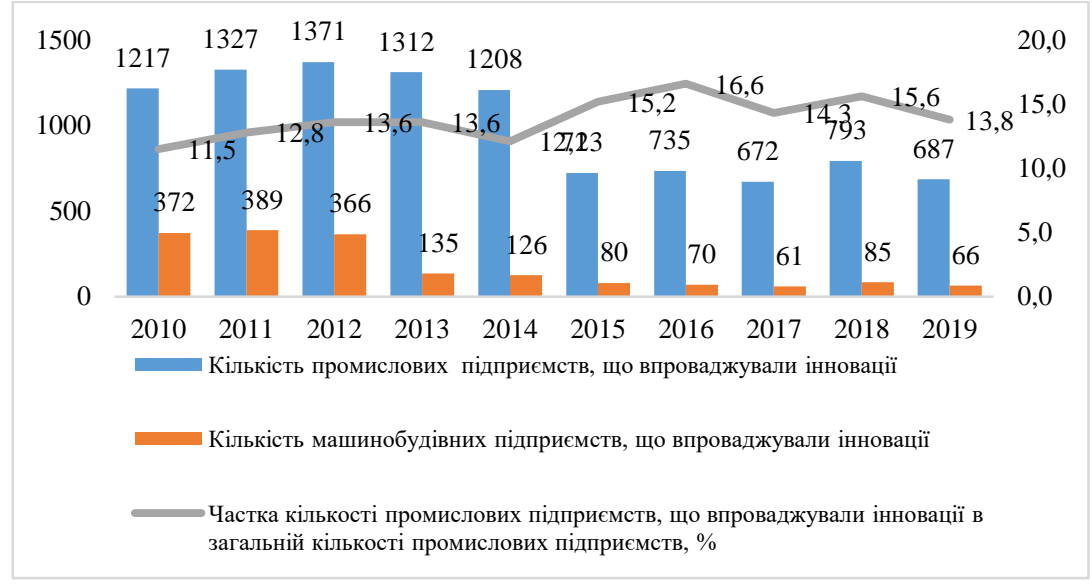

Рис. 1. Кількість промислових

та машинобудівних підприсмств, що впроваджували інновації за видами економічної діяльності

Джерело: побудовано автором за даними [3]

Так, частка промислових підприємств що впроваджували інновації за досліджуваний період коливалась в межах 11,5-16,6\%, а кількість машинобудівних підприємств які впроваджують інновації взагалі 3 кожним роком скорчується, що свідчить про проблеми інноваційного розвитку та неефективність інноваційного регулювання. Проте, слід зауважити, що світовою практикою впровадження інновацій, зокрема й через Start-Up технології відбувається на рівні Smart-підприємств, які можуть забезпечувати власну діяльність у формі малих чи мікропідприємств, які у зв'язку із неузгодженістю законодавства з 2015 року не враховуються у офіційну статистку впровадження інновацій на промислових підприємствах. 3 цього можна зробити висновки що 
падіння статистичних показників, які відображають інноваційну активність підприємств машинобудування пов'язане не лише iз проблемами їх впровадження, але й із відображення інформації у статистичних збірниках та зміню методології щодо цього.

Стимулятором державного регулювання інноваційно-технічного напряму є видатки 3 Державного бюджету на фундаментальні та прикладні дослідження у галузях економіки, зростання яких має характер стимуляторів розвитку промисловості, у тому й підприємств машинобудування (рис. 2). Саме видатки 3 державного бюджету на фундаментальні та прикладні дослідження у галузях економіки дозволяють стимулювати інноваційний розвиток підприємств, маючи стабільний безповоротний адресний характер.

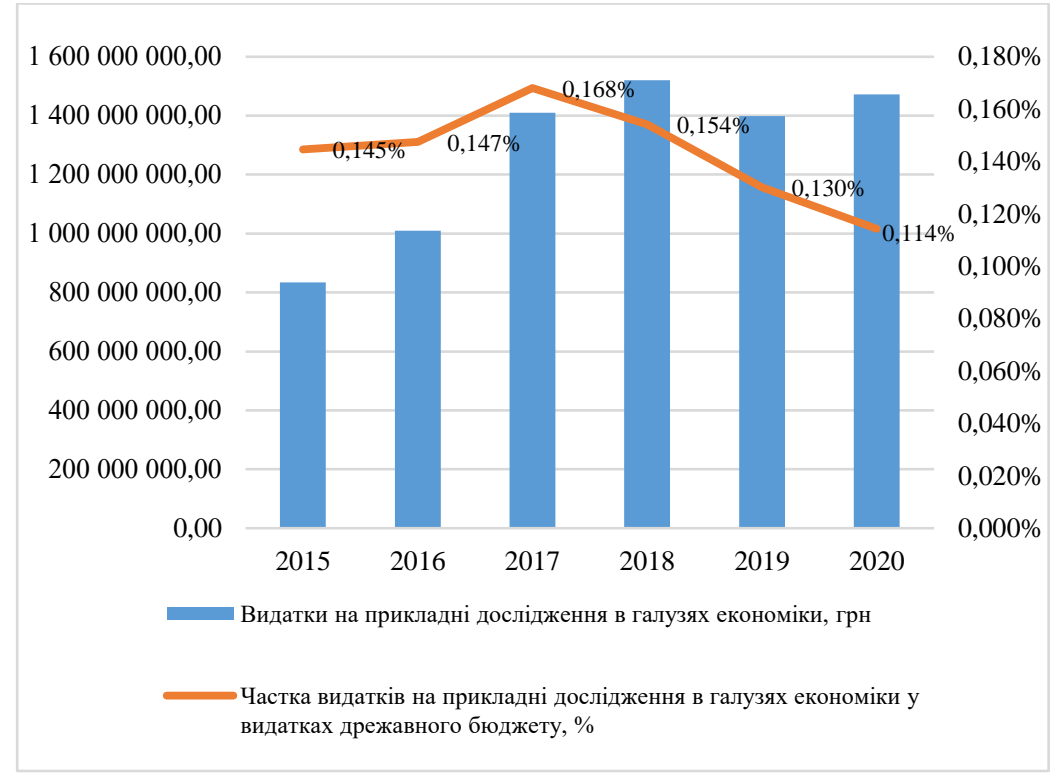

Рис. 2. Динаміка видатків на прикладні та фундаментальні дослідження, 2015-2020 pp. Джерело: побудовано автором за даними [6] 
Проте, як свідчать наведені дані за 2015-2020 роки видатки на прикладні та фундаментальні дослідження з державного бюджету скорчуються попри і так незначну частку (від 0,168\% до 0,114\%), що в свою чергу є відображенням інноваційно-технологічного регулювання держави через прямі інструменти впливу. В сучасних умовах інноваційних трансформацій значну роль державному регулюванні інновацій відіграє цифровізація підприємств, або Індустрія 4.0, яка по суті $\epsilon$ четвертою науковою революцією. Ефективність інноваційних трансформацій Індустрії 4.0 залежить від того, якою мірою безпосередні учасники, тобто держава та підприємства, зацікавлені у швидкому та економічно ефективному впровадженні нових технологій у виробництво. Значну роль відіграють методи та форми стимулювання їх праці 3 боку держави, але з іншого боку, в цифровій економіці важливим є не сам інноваційний процес, а його комерційний результат, який відображається в оновленні асортименту продукції, наданні нових споживчих якостей, розширенні ринку, зниженні витрат, підвищенні конкурентоспроможності, одержанні прибутку [2; 4].

Інноваційно-технічне державне регулювання також проявляється через формування інформаційних передумов інноваційного розвитку підприємств, яке грунтується на визначенні у суб'єктівносіїв економічних інтересів, наявних і можливих суперечностей при творенні нового продукту, нової вартості, якостей при задоволенні потреб сторін виробничо-комерційного процесу.

Разом 3 тим, можна стверджувати, що оскільки гривня стабілізувалась, то відбулось за даний період значне скорочення виробництва та купівельної спроможності як підприємств, так i населення. Відобразилось на макроекономічних показниках також відсутність результатів діяльності суб'єктів господарювання на сході України. Це вимагає структурних перетворень у фінансовій, фіскальній, виробничій сферах економіки країни, грунтуючись на особливостях розвитку продуктивних сил та виробничих відносинах з позиції стимулювання впровадження сучасних технологій [5, с. 99]. 
У контексті інноваційних перетворень галузі машинобудування України в умовах посилення технологічних викликів діжиталізації економіки державне регулювання соціальних процесів може вирішити ряд дестимуляційних впливів, перетворивши їх у стимулятори розвитку та функціонування підприємств. Одним iз основних стимуляторів соціального регулювання $є$ видатки державного бюджету на соціальний захист та соціальне забезпечення.

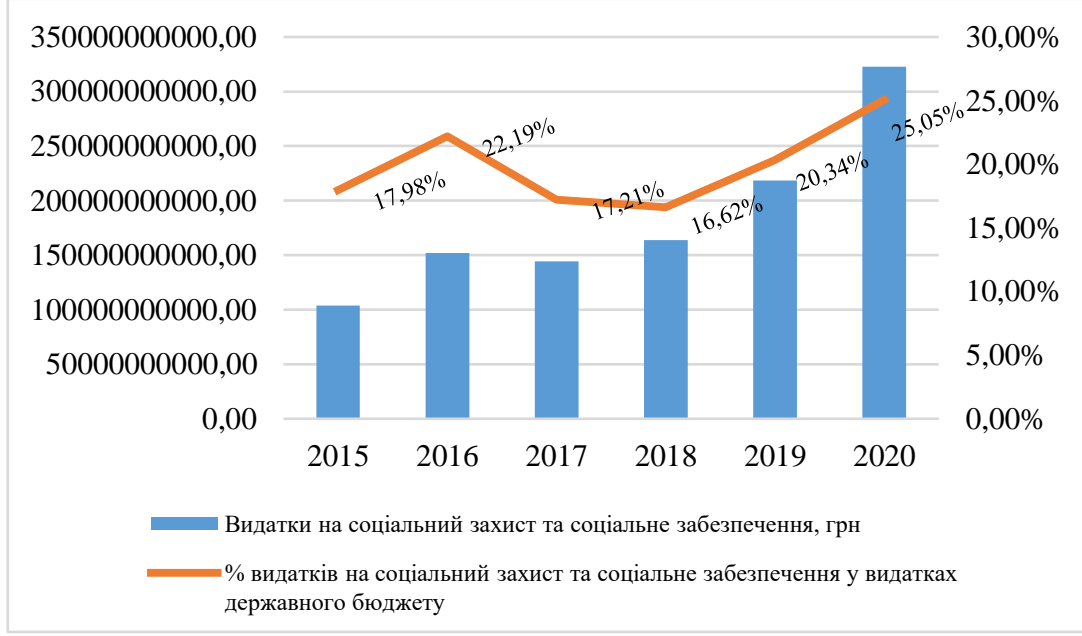

\section{Рис. 3. Динаміка видатків на соціальний захист та соціальне забезпечення, 2015-2020 pp.}

Джерело: побудовано автором за даними [6]

Видатки на соціальний захист та соціальне забезпечення забезпечують населення необхідними фінансовими ресурсами у трансформаційних динамічних процесах перетворення та реформування економіки. Зростання частки видатків на соціальний захист та соціальне забезпечення у державному бюджетів із 17,98\% у 2015 році до 20,34\% у 2019 році свідчить про стабільність даного державного регулювання та потенціал, який було частково задіяно кризовому 2020 році, коли у зв'язку із глобальною пандемією значна кількість підприємств призупи- 
няла власну діяльність, а соціальний захист набув нового значення подоланні ії дестимулюючого впливу.

Таким чином, уміле державне регулювання дозволить підприємствам машинобудування підтримувати високий рівень кваліфікації працівників, підвищення рівня ефективності діяльності, забезпечення високого рівня конкурентоспроможності та прибутковості під час кризових періодів.

\section{Література:}

1. Шушкова Ю.В. Ідентифікація чинників та перешкод реіндустріалізації економіки України на засадах інноваційно-технологічної модернізації. Бізнес Інформ. 2020. № 2. С. 141-147.

2. Кушніренко О.М. Імперативи інноваційних трансформацій промисловості України в умовах посилення технологічних викликів Індустрії 4.0. БізнесІнформ. 2020. № 2. С. 148-155.

3. Наукова та інноваційна діяльність України: Статистичний збірник / За ред. О.О. Кармазіна. Київ : Державна служба статистики України, 2019. 255 с.

4. Kwilinski A., Kuzior A. Cognitive technologies in the management and formation of directions of the priority development of industrial enterprises. Management Systems in Production Engineering. 2010. No. 28(2), pp. 133-138.

5. Ареф'єва О.В., С.Т. Пілецька, І.М. М'яких. Особливості дії інфляції та ії вплив на економіку України. Економічний вісник Донбасу. 2018. № 2 (52). C. $95-101$.

6. Державна казначейська служба України. URL: https://www.treasury.gov.ua/ua. 